\title{
Treatment of iron overload syndrome: a general review
}

\author{
Tadeu Gonçalves de Lima 1,2,3 \\ D Fernanda Luna Neri Benevides 3,4 \\ (iD) Flávio Lima Esmeraldo Filho ${ }^{1}$ \\ (iDIgor Silva Farias ${ }^{1}$ \\ DDiovana Ximenes Cavalcante Dourado ${ }^{1}$ \\ (iD) Eveline Gadelha Pereira Fontenele $e^{2,5,6}$ \\ (iD Maria Elisabete Amaral de Moraes ${ }^{6,7}$ \\ (iD) Ana Rosa Pinto Quidute $6^{6,7}$

\begin{abstract}
1. Universidade de Fortaleza - Unifor, Fortaleza, CE, Brasil 2. Hospital Universitário Walter Cantídio - UFC, Fortaleza, CE, Brasil 3. Hospital Geral César Cals de Oliveira - HGCCO, Fortaleza, CE, Brasil 4. Centro de Hematologia e Hemoterapia do Ceará - Hemoce, Fortaleza, CE, Brasil 5. Departamento de Medicina Clínica - Faculdade de Medicina - UFC, Fortaleza, CE, Brasil 6. Núcleo de Produção e Desenvolvimento de Medicamentos - NPDM - UFC, Fortaleza, CE, Brasil 7. Departamento de Fisiologia e Farmacologia- Faculdade de Medicina - UFC, Fortaleza, CE, Brasil
\end{abstract}

http://dx.doi.org/10.1590/1806-9282.65.9.1216

\section{SUMMARY}

INTRODUCTION: Iron overload is a broad syndrome with a large spectrum of causative etiologies that lead to iron deposition. When iron exceeds defenses, it causes oxidative damage and tissular disfunction. Treatment may prevent organ dysfunction, leading to greater life expectancy.

METHODS: Literature from the last five years was reviewed through the use of the PubMed database in search of treatment strategies. DISCUSSION: Different pharmacological and non-pharmacological strategies are available for the treatment of iron overload and must be used according to etiology and patient compliance. Therapeutic phlebotomy is the basis for the treatment of hereditary hemochromatosis. Transfusional overload patients and those who cannot tolerate phlebotomy need iron chelators.

CONCLUSION: Advances in the understanding of iron overload have lead to great advances in therapies and new pharmacological targets. Research has lead to better compliance with the use of oral chelators and less toxic drugs.

KEYWORDS: Iron Overload. Iron Chelating Agents. Phlebotomy. Hemochromatosis.

\section{INTRODUCTION}

Iron is essential for the transport of oxygen and to various metabolic processes ${ }^{1-3}$. This participation occurs through its potential in accepting and donating electrons, alternating between its ferrous $\left(\mathrm{Fe}^{2+}\right)$ and ferric $\left(\mathrm{Fe}^{3+}\right)$ forms ${ }^{2}$.

This oxirreductive capacity may also cause tissue damage. Ferrous iron interacts with hydrogen peroxide, generating hydroxyl radicals $(\mathrm{OH} \bullet)$, causing lipid peroxidation and damage to cellular organelles and $\mathrm{DNA}^{4}$. Due to this potential toxicity, iron homeostasis is strictly controlled. Since the human organism cannot eliminate iron, the main point of control in iron homeostasis is its absorption.

Dietary iron exists in two forms. Protein-bound iron, also known as organic or heme iron, which accounts for $10 \%$ of ingested iron, is absorbed directly. 
Non-protein-bound iron, also known as non-heme or inorganic iron, which accounts for $90 \%$ of the ingested iron, requires a broad metabolic mechanism for its absorption and transport ${ }^{2}$.

The discovery of hepcidin was one of the great steps in understanding iron metabolism and hereditary hemochromatosis $(\mathrm{HH})^{5}$. Hepcidin inhibits iron absorption, as well as its mobilization from tissues ${ }^{\mathbf{5}, \mathbf{6}}$. Most types of $\mathrm{HH}$ are based on pathophysiological changes in hepcidin synthesis.

Another way iron accumulation occurs is through either iron compounds for pharmaceutical use or repetitive transfusions, a common event in the management of patients with chronic anemia. This mechanism contributes to the mortality of individuals with hemoglobinopathies'.

Iron accumulates in the liver, endocrine glands, heart, and reticuloendothelial cells. When iron exceeds the binding capacity of apoferritin and apotransferrin, non-transferrin bound iron (NTBI) arises. A specific fraction of NTBI, called labile iron pool (LPI), has oxidative potential and is capable of cellular damage.

\section{METHODS}

We searched the PubMed Central database using the keywords: "Hemochromatosis" AND "Therapy" OR "Treatment" and "Iron Chelators". The results were filtered for the last five years and evaluated by title. We analyzed 51 articles for evaluation based on their abstracts, of which 25 were selected for the final version.

\section{Discussion (Table 1)}

The objective of treatment in iron overload is the rapid reduction of levels of NTBI and LPI, thereby reducing iron-mediated tissue lesions. Aggressive treatment before the onset of target organ damage is the key to the management of these patients, making it possible to have a normal life expectancy ${ }^{7,8}$.

\section{Non-pharmacological measures}

\section{Phlebotomies}

Therapeutic phlebotomies have been performed from the earliest stages of medicine. With the development of modern therapies, there has been a great decline in its use, but it remains one of the main forms of treatment in patients with $\mathrm{HH}^{5,9}$.

The biological rationale for the use of therapeutic phlebotomy is to force the uptake of iron by the erythroid precursors in the bone marrow, necessary to replace the erythroid mass lost through bleeding ${ }^{1}$ (Figure 1).

The introduction of phlebotomies as part of the therapy of HH patients in the 1950s increased survival and decreased disease progression when initiated in patients with clinical manifestations of iron overload. When initiated in patients in preclinical stages of the disease, it promotes survival equal to that of the healthy population.

The appropriate timing to start phlebotomies in

TABLE 1. TREATMENTS FOR IRON OVERLOAD SYNDROME

\begin{tabular}{|c|c|c|c|c|}
\hline Treatment & Main Indication & Mechanism of Action & Comments & References \\
\hline $\begin{array}{l}\text { Therapeutic } \\
\text { Phlebotomy }\end{array}$ & $\begin{array}{l}\text { Hereditary } \\
\text { hemochromatosis }\end{array}$ & $\begin{array}{l}\text { Increased Iron } \\
\text { Mobilization to Bone } \\
\text { Marrow }\end{array}$ & $\begin{array}{l}\text { Choice treatment for Hereditary } \\
\text { Hemochromatosis } \\
\text { Low cost, Safe and Effective }\end{array}$ & $1,3-6,10,11$ \\
\hline Erythrocytoapheresis & $\begin{array}{l}\text { Hereditary } \\
\text { hemochromatosis }\end{array}$ & $\begin{array}{l}\text { Increased Iron } \\
\text { Mobilization to Bone } \\
\text { Marrow }\end{array}$ & $\begin{array}{l}\text { Indicated in patients with severe heart disease } \\
\text { High cost (2-3x phlebotomy costs) }\end{array}$ & $11,12,13$ \\
\hline Desferrioxamine & $\begin{array}{l}\text { Secondary } \\
\text { hemosiderosis }\end{array}$ & $\begin{array}{l}\text { Iron binding and } \\
\text { elimination }\end{array}$ & $\begin{array}{l}\text { Earliest chelator } \\
\text { Parenteral use with continuous infusion }\end{array}$ & $15-21$ \\
\hline Deferiprone & $\begin{array}{l}\text { Secondary } \\
\text { hemosiderosis }\end{array}$ & $\begin{array}{l}\text { Iron binding and } \\
\text { elimination }\end{array}$ & $\begin{array}{l}\text { Oral use - } 3 \text { daily dose regimen } \\
\text { Option in heart iron overload and mitochondrial } \\
\text { iron overload, as Friedreich's Ataxia or }\end{array}$ & $15-24$ \\
\hline Deferasirox & $\begin{array}{l}\text { Secondary } \\
\text { hemosiderosis }\end{array}$ & $\begin{array}{l}\text { Iron binding and } \\
\text { elimination }\end{array}$ & $\begin{array}{l}\text { Newest chelator, main chelator agent in Brasil } \\
\text { Oral use -Single daily dose regimen }\end{array}$ & $15,18-21,23-29$ \\
\hline Deferitrin & $\begin{array}{l}\text { Secondary } \\
\text { hemosiderosis }\end{array}$ & $\begin{array}{l}\text { Iron binding and } \\
\text { elimination }\end{array}$ & $\begin{array}{l}\text { Clinical investigations suspended after } \\
\text { nephrotoxicity in Phase- } 1 \text { trials }\end{array}$ & 15,16 \\
\hline Deferitazole & $\begin{array}{l}\text { Secondary } \\
\text { hemosiderosis }\end{array}$ & $\begin{array}{l}\text { Iron binding and } \\
\text { elimination }\end{array}$ & Phase- 2 and -3 trials are being performed & 15.16 \\
\hline Mini-hepcidins & $\begin{array}{l}\text { Hereditary } \\
\text { hemochromatosis }\end{array}$ & $\begin{array}{l}\text { Decreases iron } \\
\text { absorption }\end{array}$ & $\begin{array}{l}\text { Active fraction of the hormone hepcidin. } \\
\text { Pre-clinical studies }\end{array}$ & $4,7,30,31$ \\
\hline
\end{tabular}




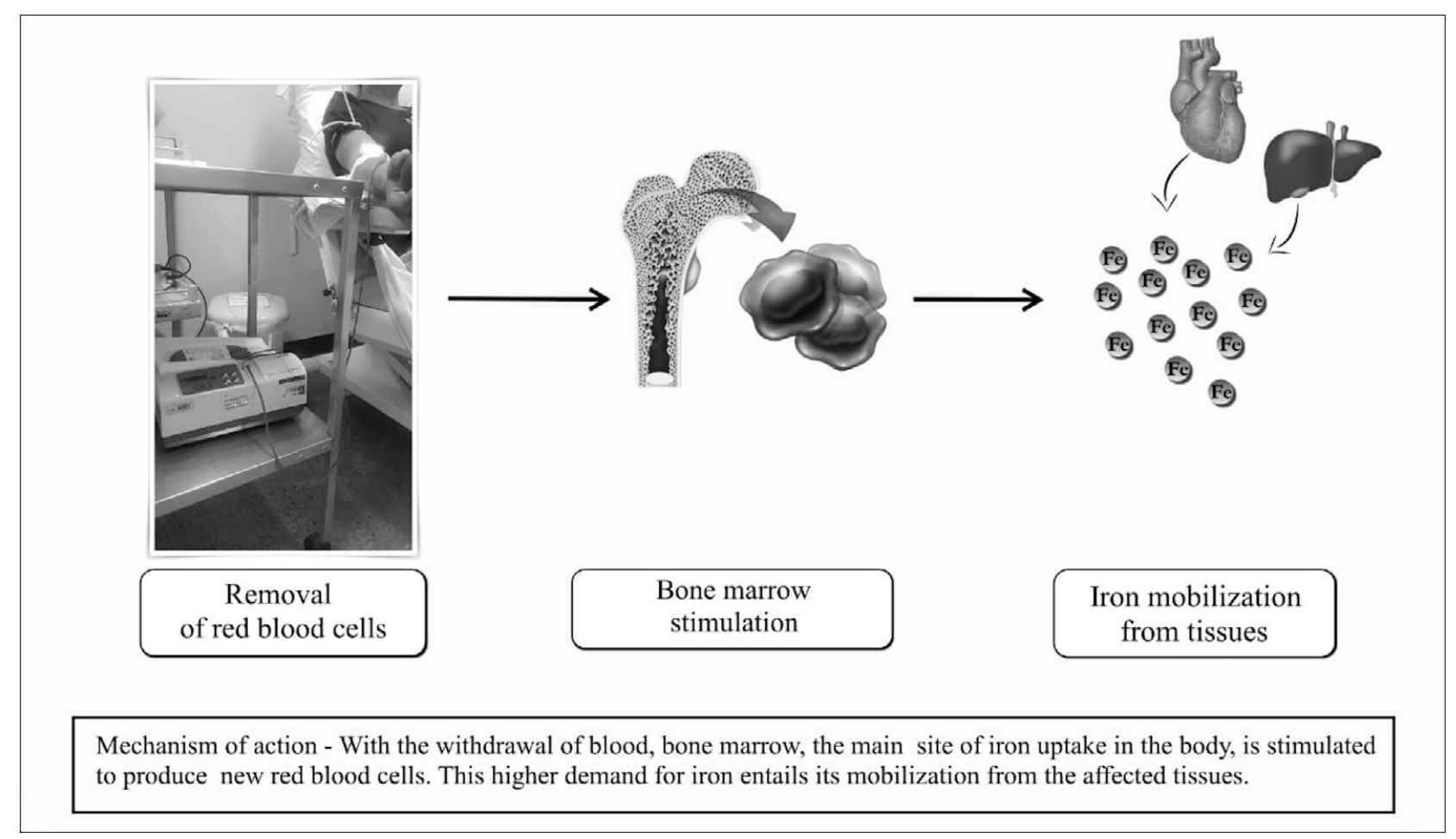

FIGURE 2. IRON CHELATORS

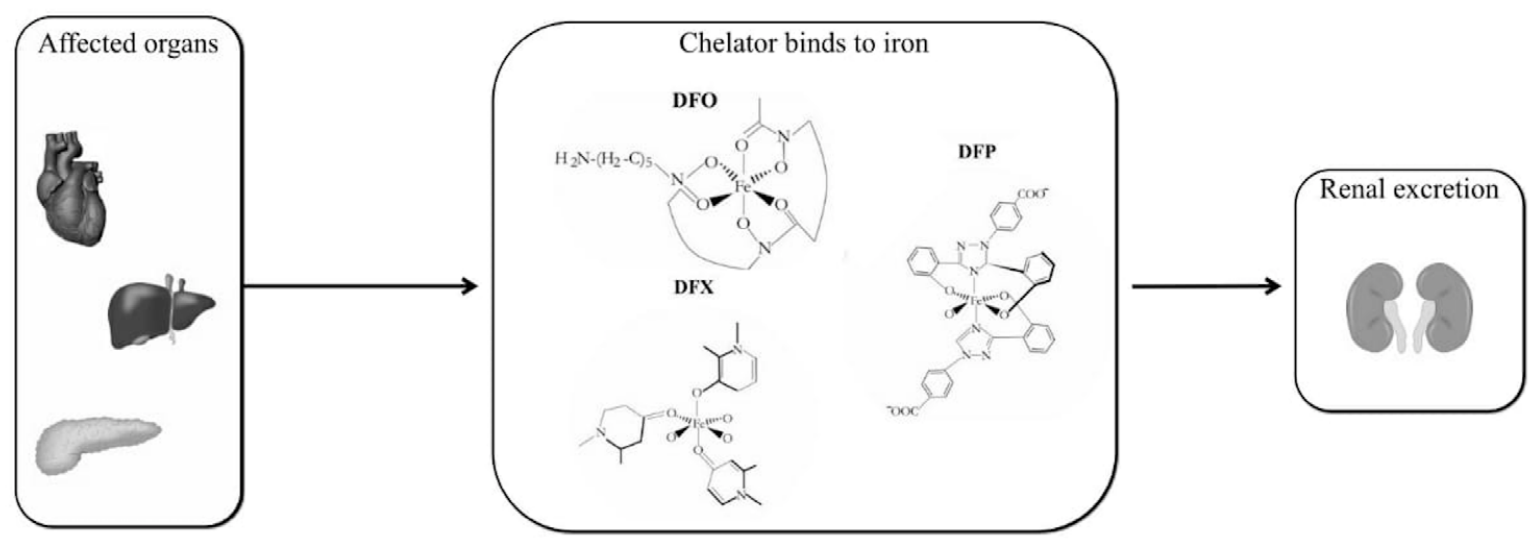

Mechanism of action - Iron chelators are molecules capable of binding to iron in tissues, allowing them to be excreted. The main chelators used nowadays, Deferoxamine (DFO), Deferiprone (DFP) and Deferasirox (DFX) form complexes of 1 (DFO), 2 (DFX) or 3 (DFP) chelating molecules for each molecule of iron, blocking its oxi-reduction capacity and allowing excretion of the iron through the kidney.

patients diagnosed with HH is not consensually defined among the different Hepatology and Hematology societies. The American Society of Hematology (ASH) proposes to start phlebotomies when ferritin levels are above $300 \mu \mathrm{g} / \mathrm{L}$ in men or $200 \mu \mathrm{g} / \mathrm{L}$ in women of childbearing potential. American (AASLD) and European (EASL) hepatology societies recommend starting as soon as ferritin levels are above the upper limits of normality, regardless of symptoms or clinical manifestations ${ }^{4}$. The Mi-iron study on the use of phlebotomies in patients with mild iron overload (between the upper limit of normalcy and $1000 \mu \mathrm{g} / \mathrm{L}$ ) is currently underway ${ }^{4}$.

The amount of blood withdrawn at each session is around $7 \mathrm{ml} / \mathrm{kg}$ body weight (maximum of 400-550 $\mathrm{ml}$ of blood). Sessions usually occur weekly or biweekly during the initial phase of treatment, and hemoglobin levels should be assessed before each session to avoid anemia ${ }^{4}$. Withdrawal of approximately $0.5 \mathrm{mg}$ of iron for every $1 \mathrm{ml}$ of blood withdrawn is 
estimated, which would roughly correspond to a decrease in serum ferritin by $30 \mu \mathrm{g} / \mathrm{L}$ at each session ${ }^{3}$.

Another controversial point is the target for ferritin in the first stage of the treatment. AASLD recommends reducing ferritin levels to a range between 50 and $100 \mu \mathrm{g} / \mathrm{L}$. EASL recommends more liberal levels in the initial phase, aiming for a ferritin level below $300 \mu \mathrm{g} / \mathrm{L}^{4}$. Some authors recommend bringing ferritin closer to the levels of iron deficiency, below $50 \mu \mathrm{g} /$ L. Ferritin levels must be monitored every three months ${ }^{4,9}$.

In the maintenance stage, the frequency of phlebotomies is reduced to every four to six months, depending on the trends of ferritin levels. The aim at this stage is to keep ferritin levels between 50 and $100 \mu \mathrm{g} / \mathrm{L}^{4,9}$.

The most common adverse events during phlebotomies are local manifestations such as pain or bruising at the puncture site. Hemodynamic changes due to phlebotomy are usually mild and may present as fatigue or syncope, but it can be a limiting factor, especially in those with cardiopathies. The consumption of large volumes of water on the day of phlebotomies is recommended as a way of reducing hemodynamic manifestations ${ }^{4}$.

\section{Erythrocytoapheresis}

Erythrocytoapheresis is a technique that selectively removes erythrocytes, returning blood components such as leukocytes, platelets, and plasma. This selective withdrawal of red blood cells allows for a greater withdrawal of iron, as well as decreases the hemodynamic events related to phlebotomies, being more indicated in patients with severe heart disease ${ }^{10,11}$.

In two randomized controlled trials ${ }^{10,11}$, erythrocytapheresis was found to be a viable alternative to phlebotomy. Because a increased erythrocyte mass is withdrawn in each session, normalization of ferritin was faster and with fewer sessions, but final ferritin levels were similar between the groups.

Among the adverse events related to erythrocytapheresis, most were related to the use of citrate as an anticoagulant. By promoting calcium chelation, citrate may lead to nausea, paresthesias, or cramps ${ }^{10,11}$. These events were rare, between 0.4 and $8 \%^{10,11}$.

A major limiting factor to erythrocytapheresis are the costs involved, two ${ }^{10}$ to three ${ }^{11}$ times more expensive than those of phlebotomy, and the need for specific equipment and trained technicians. The use of erythrocytapheresis in selected patients may be useful in cases of severe heart disease.

\section{Dietary changes}

Daily iron intake is around $15-25 \mathrm{mg} /$ day. Some studies have sought to identify whether dietary iron restriction or measures that change iron bioavailability, such as consumption of non-citrus fruits, tea, or proton pump inhibitors, could contribute to the treatment of patients with iron overload.

Moretti et al. ${ }^{12}$ found a small effect on iron absorption and serum ferritin levels with dietary interventions, but the impact these changes may have on the absorption of other nutrients need to be better evaluated. There are currently no consensual indications of routine iron restriction or measures that reduce the bioavailability of iron.

It is recommended to restrict the consumption of seafood due to the increased risk of Vibrio vulnificus and Yersinia enterocolitica infections ${ }^{2,5}$. Alcohol consumption is also not recommended because of the potential hepatic injury and interference with hepcidin secretion ${ }^{4,5}$. Iron and Vitamin C supplementation are formally contraindicated ${ }^{5,7}$.

\section{Pharmacological measures}

Therapeutic phlebotomy, although an extremely useful measure in patients with hemochromatosis, cannot be performed in patients with chronic anemia. In these patients, iron withdrawal should be performed by substances that bind to iron in tissues and allow their excretion, namely iron chelators (Figure 2).

Three chelating substances are available for clinical use: deferoxamine (DFO), deferiprone (DFP), and deferasirox (DFX). We will review the characteristics of each of these substances in detail below.

\section{Desferrioxamine}

Deferoxamine (DFO) is a compound discovered in 1960 produced by Streptomyces pilosus and used since the 1970s in cases of iron overload. Its large molecule is highly hydrophilic and gives six fixing points (hexadentate ligand) to iron, in order to allow the formation of complexes in a 1:1 ratio ${ }^{13,14}$.

This molecular structure hinders oral absorption; it needs to be administered parenterally, most commonly subcutaneous. Once in circulation, much of the DFO enters hepatocytes. Once inside the hepatocytes, complexes are formed, protecting the iron 
from potential endogenous reducers, avoiding its toxicity ${ }^{14}$. The complex is then eliminated through urinary and fecal routes.

Because of its very short elimination half-life, around 10 to 30 minutes, continuous drug infusion is necessary ${ }^{13-15}$. This contributes to a decrease in patients' adherence to therapy.

The starting dose recommended is 20 to $40 \mathrm{mg} /$ $\mathrm{kg}$, infused over 8 to 24 hours subcutaneously or intravenously, 5 to 7 times a week ${ }^{14-16}$. Higher doses, up to $60 \mathrm{mg} / \mathrm{kg}$, may be used in exceptional situations but should be avoided, especially in children because of the toxicity ${ }^{16,17}$.

Most reported adverse events are related to local reactions at infusion sites ${ }^{14-17}$. Ocular and ototoxicity are also described and must be monitored at least once a year. Iron mobilization may provide iron to siderophore pathogens such as Yersinia enterocoliti$c a$ and Vibrio vulnificus, increasing the risk of infections ${ }^{17}$.

\section{Deferiprone}

Deferiprone (DFP) was the first chelating agent with good oral absorption in clinical practice. It was synthesized in 1982 and initially approved for use in 1995 in India and in 2000 in Europe. The USFDA approved its use only in 2011 as rescue therapy in patients with thalassemia who had an insufficient response to the available treatments ${ }^{13,18}$.

The molecular structure of deferiprone has two attachment points for iron (bidentate ligand), allowing the formation of complexes at a 3:1 ratio. When the iron concentration exceeds that of DFP, 2:1 positively charged complexes are formed which are unable to fully protect the iron from endogenous reductants ${ }^{13}$.

Its lipophilic molecule is the smallest among the three chelators, allowing for good oral bioavailability and better penetration in several tissues and in specific structures within the cell, such as the mitochondria. DFP may be a therapeutic option in other conditions related to iron metabolism, such as Friedreich's ataxia ${ }^{18}$.

The main route of drug metabolism is through glucuronidation of the hydroxyl radical ${ }^{13}$. The compound is soluble and excreted in the urine. Its halflife is around 3 to 4 hours, and multiple daily doses are needed $\mathrm{d}^{14,18}$.

The initial dose recommended is 75 to $100 \mathrm{mg} / \mathrm{kg}$ a day, divided into three daily doses ${ }^{14,18}$. It has efficacy equivalent to $\mathrm{DFO}^{18}$ and in severely loaded pa- tients, especially those with severe cardiac siderosis, DFP can be associated with DFO, showing a synergistic effect ${ }^{18,19}$. There is no definitive data for the use of this drug in the pediatric population under 6 years of age ${ }^{15-17}$.

The worse adverse event related to DFP is neutropenia $^{13-17}$, rarely culminating in agranulocytosis, which limits its routine clinical use. A weekly evaluation of leukocyte counts is recommended in patients taking deferiprone. Other side effects are arthralgia, hepatotoxicity, and gastrointestinal discomfort. There are isolated reports of drug-induced lupus and heart failure.

\section{Deferasirox}

Deferasirox (DFX) is the newest molecule among those clinically available. It was synthesized in 2002 by Novartis in a prospection program that included more than 700 molecules $^{13}$. It was approved for clinical use in 2005 and 2006 by the USFDA and the European Union regulatory agency and rapidly became one of the major iron-chelating agents in clinical practice $^{19-21}$.

The molecular structure of DFX provides three points of attachment to iron (tridentate ligand), which allows the formation of complexes in a 2:1 ratio. At physiological $\mathrm{pH}$ conditions, the complexes formed are negatively charged, which makes them chemically incapable of reacting with the endogenous reducing agents ${ }^{13}$.

Its oral bioavailability is around $70 \%$. Another pharmacokinetic characteristic is its prolonged halflife, around 8 to 16 hours. This feature allows the use of DFX in a single daily dose $\mathrm{e}^{20,21}$.

The main route of excretion of the drug is fecal, with more than $60 \%$ of the drug eliminated in its natural form. It also can be metabolized by liver enzymes and eliminated by the renal route. This metabolic pathway accounts for approximately $8 \%$ of drug elimination. A small part is metabolized by the cytochrome p450 system ${ }^{21}$.

The starting dose recommended of DFX is $20 \mathrm{mg} /$ $\mathrm{kg}$ a day and can be increased up to $40 \mathrm{mg} / \mathrm{kg}$ a day. In patients with moderate hepatic impairment (ChildPugh score B) a 50\% reduction in the initial dose and closer monitoring for adverse events is recommended. DFX is not recommended for patients with severe hepatic impairment (Child-Pugh score C). There are few studies in patients with severe renal impairment, and there is no specific recommendation for dose ad- 
justment in this population, but caution is advised in dialytic patients ${ }^{21}$. Studies in children demonstrate the safety of this drug, and it can also be used in patients older than 2 years old ${ }^{15,16}$.

Several studies have demonstrated good efficacy in the reduction of iron deposits in several tissues ${ }^{22-24}$. In case of severe heart siderosis, the association with DFP has shown a synergistic effect ${ }^{18,22-24}$.

Most adverse events related to DFX are of gastrointestinal origin ${ }^{15-17,21}$, symptoms such as nausea, vomiting, diarrhea, and abdominal pain are common but usually mild and transient. In some cases, they can be a limiting factor to the escalation of the dose. A consideration to be made is the presence of lactose in the tablet composition, which may be the cause of the symptoms in intolerant patients.

Some of the serious adverse events related to DFX are hepatotoxicity and nephrotoxicity. These events usually manifest as mild changes in laboratory tests, with no clinical manifestations, but monthly monitoring of creatinine levels and liver enzymes is necessary.

\section{Future perspectives}

\section{New chelators}

Several new compounds are under study as new promises for clinical use as iron chelators. Some compounds studied at the moment are of the 3-hydroxy-4-pyridinone family. Several changes in the molecular structure have demonstrated compounds with better iron-binding capacity than Deferiprone in preclinical testing. Phase-1 clinical trials with some of these compounds are ongoing ${ }^{13}$.

Another molecule with good in vitro potential for iron chelation was Deferitrin, but investigations were suspended after three cases of nephrotoxicity in a phase $1 \mathrm{study}^{13,14}$. Several changes in the structure of the molecule are being evaluated in preclinical studies in an attempt to reduce this toxicity.
Phase-2 and -3 studies are being performed on the compound Deferitazole ${ }^{13,14}$. This compound is a derivative of desferythycin, a natural siderophore extracted from Streptomyces antibioticus, which has demonstrated long half-life, allowing daily dosing, and low toxicity.

\section{Mini-hepcidins}

Due to its unique chemical structure with four disulfide bridges, hepcidin is extremely difficult to synthesize. Studies with computational modeling and amino acid substitution were able to synthesize compounds from hepcidin fragments with biological activity, the mini-hepcidins ${ }^{6}$.

Studies in murine models ${ }^{25}$ have shown favorable results in decreasing iron absorption, demonstrating a potential use of these drugs in preclinical states or in conjunction with iron chelation or therapeutic phlebotomies.

\section{Final considerations}

Research with iron chelators has made possible a better adherence, with the discovery of oral substances with a good profile of side effects. With the advancement of research, we expect the emergence of more potent and less toxic drugs.

Recent advances in the understanding of iron overload syndrome have led to major advances in the therapy of these patients, with promises of addressing new pharmacological targets with new Hepcidin agonists.

\section{CONFLITS OF INTEREST}

The Authors declare no conflicts of interest that may have influenced this work.

\section{Authors' Contributions:}

All authors have reviewed and approved the final text of the article and are responsible for its content.

\section{RESUMO}

INTRODUção: A síndrome de sobrecarga de ferro engloba um grande espectro de etiologias que levam a um aumento da quantidade de ferro nos tecidos. Esse ferro excede a capacidade de proteção dos tecidos, levando a dano oxidativo e lesão tissular. Tratamento pode prevenir esse dano, levando à melhor sobrevida.

METODOLOGIA: A literatura dos últimos cinco anos foi revisada por meio de pesquisa na base de dados PubMed buscando identificar estratégias de tratamento.

DISCUSSÃo: Medidas farmacológicas e não farmacológicas estão disponíveis para o tratamento da síndrome de sobrecarga de ferro e devem ser utilizadas de acordo com a etiologia e a aceitação do paciente. A flebotomia terapêutica é base do tratamento dos pacientes com hemocromatose hereditária. Pacientes com sobrecarga transfusional ou aqueles que não toleram flebotomias devem utilizar quelantes de ferro. 
CONSIDERAÇõES FINAIS: AvançOs no entendimento da síndrome de sobrecarga de ferro têm levado a grandes progressos na terapêutica, com promessas de abordagem de novos alvos farmacológicos. A evolução da pesquisa tem possibilitado melhor aderência com o uso de quelantes orais e com possibilidade de drogas menos tóxicas.

PALAVRAS-CHAVE: Sobrecarga de ferro. Quelantes de ferro. Flebotomia. Hemocromatose.

\section{REFERENCES}

1. Brissot P. Optimizing the diagnosis and the treatment of iron overload diseases. Expert Rev Gastroenterol Hepatol. 2016;10(3):359-70.

2. Thachill J, Solberg LA, Khan Jr MJ, McCrae KR. Iron metabolism, iron overload and the porphyrias. In: ASH-SAP: American Society of Hematology self-assessment program. Washington: American Society of Hematology; 2013.

3. Crownover BK, Covey C). Hereditary hemochromatosis. Am Fam Physician. 2013;87(3):183-90.

4. Powell LW, Seckington RC, Deugnier Y. Haemochromatosis. Lancet. 2016;388(10045):706-16.

5. Barton IC. Hemochromatosis and iron overload: from bench to clinic. Am Jed Sci. 2013;346(5):403-12.

6. Chua K, Fung E, Micewicz ED, Ganz T, Nemeth E, Ruchala P. Small cyclic agonists of iron regulatory hormone hepcidin. Bioorg Med Chem Lett. 2015;25(21):4961-9.

7. Salgia RJ, Brown K. Diagnosis and management of hereditary hemochromatosis. Clin Liver Dis. 2015;19(1):187-98.

8. Mohamed M, Phillips J. Hereditary haemochromatosis. BMJ. 2016;353:i3128.

9. Assi TB, Baz E. Current applications of therapeutic phlebotomy. Blood Transfus. 2014;12(Suppl 1):s75-83.

10. Rombout-Sestrienkova E, Winkens B, Essers BA, Nieman FH, Noord PA, Janssen MC, et al. Erythrocytapheresis versus phlebotomy in the maintenance treatment of HFE hemochromatosis patients: results from a randomized crossover trial. Transfusion. 2016;56(1):261-70.

11. Sundic T, Hervig T, Hannisdal S, Assmus J, Ulvik RJ, Olaussen RW. Erythrocytapheresis compared with whole blood phlebotomy for the treatment of hereditary haemochromatosis. Blood Transfus. 2014;12(Suppl 1):s84-9.

12. Moretti D, van Doorn GM, Swinkels DW, Melse-Boonstra A. Relevance of dietary iron intake and bioavailability in the management of HFE hemochromatosis: a systematic review. Am J Clin Nutr. 2013;98(2):468-79.

13. Nurchi VM, Crisponi G, Lachowicz II, Medici S, Peana M, Zoroddu MA Chemical features of in use and in progress chelators for iron overload. Trace Elem Med Biol. 2016;38:10-8.
14. Sheth S. Iron chelation: an update. Curr Opin Hematol. 2014;21(3):179-85

15. Botzenhardt S, Li N, Chan EW, Sing CW, Wong IC, Neubert A. Safety profiles of iron chelators in young patients with haemoglobinopathies. Eur Haematol. 2017;98(3):198-217.

16. Kontoghiorghes $\mathrm{CN}$, Kontoghiorghe $\mathrm{Gl}$. Efficacy and safety of iron-chelation therapy with deferoxamine, deferiprone, and deferasirox for the treatment of iron-loaded patients with non-transfusion-dependent thalassemia syndromes. Drug Des Devel Ther. 2016;10:465-81.

17. Saliba AN, El Rassi F, Taher AT. Clinical monitoring and management of complications related to chelation therapy in patients with $\beta$-thalassemia. Expert Rev Hematol. 2016;9(2):151-68.

18. Belmont A, Kwiatkowski JL. Deferiprone for the treatment of transfusional iron overload in thalassemia. Expert Rev Hematol. 2017;10(6):493-503.

19. Wongjaikam S, Kumfu S, Chattipakorn SC, Fucharoen S, Chattipakorn N. Current and future treatment strategies for iron overload cardiomyopathy. Eur | Pharmacol. 2015;765:86-93.

20. Allegra S, De Francia S, Cusato |, Pirro E, Massano D, Piga A, et al. Deferasirox pharmacokinetic and toxicity correlation in $\beta$-thalassaemia major treatment. J Pharm Pharmacol. 2016;68(11):1417-21.

21. Tanaka C. Clinical pharmacology of deferasirox. Clin Pharmacokinet. 2014;53(8):679-94.

22. Totadri S, Bansal D, Bhatia P, Attri SV, Trehan A, Marwaha RK. The deferiprone and deferasirox combination is efficacious in iron overloaded patients with $\beta$-thalassemia major: a prospective, single center, open-label study. Pediatr Blood Cancer. 2015;62(9):1592-6.

23. Piga A, Longo F, Origa R, Roggero S, Pinna F, Zappu A, et al. Deferasirox for cardiac siderosis in $\beta$-thalassaemia major: a multicentre, open label, prospective study. Br J Haematol. 2014;167(3):423-6.

24. Vlachaki E, Agapidou A, Spanos G, Klonizakis P, Vetsiou E, Mavroudi M, et al. Five years of deferasirox therapy for cardiac iron in $\beta$-thalassemia major. Hemoglobin. 2015;39(5):299-304.

25. Ramos E, Ruchala P, Goodnough JB, Kautz L, Preza GC, Nemeth E, et al. Minihepcidins prevent iron overload in a hepcidin-deficient mouse model of severe hemochromatosis. Blood. 2012;120(18):3829-36. 